\title{
Centromere IgG Antibody Measurement
}

National Cancer Institute

\section{Source}

National Cancer Institute. Centromere IgG Antibody Measurement. NCI Thesaurus. Code C122111.

The determination of the amount of centromere IgG antibody present in a biological specimen. 